\title{
The New Era of Brazilian Football and Clubs Managed as a Business
}

\author{
A Nova Era do Futebol Brasileiro e Clubes Geridos como Negócio
}

\author{
Wilson Toshiro Nakamura' ${ }^{1}$ \\ Sérgio de Albuquerque Cerqueira ${ }^{2} \odot$

\footnotetext{
${ }^{1}$ Statutory Director and Board Member of Sociedade Esportiva Palmeiras, São Paulo, SP, Brazil
} \\ ${ }^{2}$ Former Chairman of the Fiscal Council and former Director of the Botafogo de Futebol e Regatas, Rio de Janeiro, RJ, Brazil
}

Football is a national passion. Everyone in Brazil has heard this phrase at some time. And it expresses an irreproachable truth. Indeed, if there is a genuinely popular sport in the largest country in Latin America that at the same time attracts the interest of people from all social classes, it is football. Especially men like football and often say they are passionate about their clubs, but there is a clear growth in the number of women who have become interested in the sport and go to the stadiums.

Soccer in Brazil is recognized worldwide for the refined technique of its athletes. Many Brazilian players stood out in the global context, including Pelé, mainly, but also Garrincha, Rivelino, Ronaldinho (Ronaldo Fenômeno), Ronaldinho Gaúcho, Kaká, Romário, Neymar, among a multitude of great athletes who left, or still leave, their identity as legendary athletes and of extraordinary value.

But, especially in the 21 st century, we have experienced a major transformation in the global football industry, in which, in major football centers, many clubs have been managed with much more competence and adopting some of the best practices observed in the corporate world. This happened mainly in countries like England, Germany, Spain, France, Italy, and Portugal, just to name a few European cases.

Many of these clubs were conceived as companies many decades ago, especially in England, but, in addition, they have modernized a lot in recent times, while others made the change from club in an associative model to club in a business model in most recent periods. Bayern Munich, for example, was a club based on the associative model (non-profit) and became a company in 1992, this passage being well described and discussed in several specialized publications. In England, clubs in general, participating in the Premier League, are companies and some of them have started to attract fans and supporters globally. That is, they became international. However, we also have the case of Real Madrid and FC Barcelona, which are clubs in the associative model, but, as a matter of fact, they are managed as if they were companies, in addition to having a high standard of governance. 
It is worth considering that, in the context of South America, in some countries there are clubs, among the main ones, structured as companies, such as Chile, Peru, and Colombia, while in Argentina a model similar to the Brazilian one prevails, especially when we refer to River Plate and Boca Juniors, the most prominent clubs in this country.

In Brazil, although there has been a great evolution in management practices, especially in the last five to ten years, there is undoubtedly still a long way to go before we can achieve an economic status more comparable to the biggest centers of world football. In addition, none of the most important clubs is structured, from a legal point of view, as a company. They are all clubs in the associative, non-profit model.

This stage of evolution, which football goes through globally, and Brazil in particular, opens a window of opportunity for many new academic researches to be carried out in the context of this industry, which is consolidating itself and gaining more and more relevance in the economic context, with research in the field of sports marketing, but also in other areas such as: finance in sports, management of stadiums and major events, strategies in the sports field, internationalization, leadership and people management in sports entities, etc.

According to the Brazilian Football Impact report, published by EY of Brazil with data from 2018, the production chain of Brazilian football has a $0.72 \%$ share in the Brazilian GDP (Confederação Brasileira de Futebol $[\mathrm{CBF}], 2019)$. Also according to this report, Brazilian football generated R $\$ 52.9$ billion in 2018 as well as generated approximately 156,000 jobs (CBF, 2019). We have, in Brazil, more than 7,000 clubs (of which only 874 are active professional clubs) and more than 360,000 registered athletes. These are significant numbers, but they have great potential to be improved, especially in terms of the participation of the football industry in the country's GDP, which could triple, according to a statement by Rogério Caboclo, current president of $\mathrm{CBF}$ - Brazilian Football Confederation.

A significant fact that deserves to be highlighted is the digital transformation that has gone through several industries in the market and that is also arriving in the world of football. The digital tools, as well as the communication and relationship possibilities that can be explored on social networks, are a world of endless opportunities, which are certainly already competently being used by some of the main clubs in Europe, such as FC Barcelona, Liverpool, and Manchester United, just to name a few. Above all, a clearer scenario of the use of streaming is being revealed in the broadcasting of sporting events, which will give the internet a much more relevant role in terms of allowing more people in different places to have access, with flexibility and autonomy, to innumerable football matches that are held around the world.

It is interesting to understand the logic of football clubs in Brazil. They usually have a social headquarters and physical facilities, which allows the practice of sports and recreational and social activities by their members. It is precisely in the ambit of the associates that the directors emerge, who are elected periodically (every four years, for example), although many of them may have reached the status of lifetime directors, which gives them the right to remain as directors indefinitely, without the need for reelection. Club directors are part of the so-called deliberative council, the club's highest decision-making body, although some issues have to be put to a vote in a member assembly, which would function as a direct voting mechanism for some matters considered most relevant.

The activities of professional football and development of new athletes, in turn, are administered in a structure independent of the other activities of the club. They are $100 \%$ professionalized, involving professionals in the areas of sports science, physical, medical, physiotherapy, physiology, logistics, press and communication, etc. Usually, all these activities are led by a manager responsible for all professional football activities and, often, also involving the training of new athletes. This manager can be someone who exercises the position voluntarily, without remuneration, or by someone remunerated and hired in the market.

Clubs generate revenue through different sources, but mainly related to professional football activities. The main sources are: broadcasting rights for games in different championships, match day income, partner-fan program, sponsorship, and sale of athletes. The relative importance of each source varies from club to club, but in general, broadcasting rights are still the main source of revenue. Here in Brazil, the main clubs participate in the Brazilian Championship, the Brazilian Cup, and the state or regional championships. The first two are organized by CBF Brazilian Football Confederation. In addition, some clubs are eligible to participate in two international tournaments: Libertadores and Sudamericana, both organized by CONMEBOL - South American Football Confederation.

Whenever hosting matches the clubs generate income, bearing a high cost for the operation of the event. Therefore, in general, there is a minimum number of audiences below which clubs generate losses. Most clubs' partner-supporter programs are mainly geared toward the advance sale of tickets and priority in purchasing by members in matches in high demand. Therefore, it is customary to consolidate the matchday income with the revenues of the partner-supporter program as if it were a single source. 
Another source of revenue that has gained importance over time is sponsorships, especially stamping sponsors' brands on their uniforms. In addition, many Brazilian clubs systematically generate revenue through the sale of professional athletes, the most significant values being obtained with transfers abroad, especially to Europe.

One of the large challenges for Brazilian clubs lies in their financial equation, as many of them are highly indebted and paying high costs on these debts. This level of indebtedness has grown over time, but has grown less than proportionally in relation to revenues, which shows something favorable. However, clubs in general are unable to generate surpluses, although some have achieved this more recently. Therefore, raising revenue levels while seeking to work at lower costs is an undeniable path that clubs will have to take to resolve their current financial situation, increase their investment capacity, and thus become more comparable to the main clubs in the world. Basically, it is up to the clubs to generate higher levels of revenue and seek to ensure a level of margin sufficiently high to allow them to pay off debts gradually and, at the same time, invest in their infrastructure (including technology), in their training activities for new athletes and in hiring athletes from the market to build competitive teams.

To enhance their business, Brazilian clubs need to make use of many of the practices already established in the corporate world, involving digital marketing, creation of innovative products and services, improvement and digitalization of processes, strategic partnerships, adoption of zero-based budgeting, use of business intelligence tools, among other initiatives. In order to observe a consistent evolution of the businesses, it is also essential that good governance practices and strategic planning are adopted.

With regard to governance, this evolution will occur more significantly when the clubs become a company, remembering that there are two proposals in progress in the National Congress of Brazil for this purpose. Improving governance implies the need to create a board of directors along the lines of publicly-held companies, professionalizing management by hiring highly qualified executives, remunerated according to modern criteria based on incentives, and, not least, evolving in practices of transparency, with better and more detailed presentation of financial information.
For the researchers in the Business Administration area, we propose some ideas that can be evolved, generating good research projects, either in the Brazilian or in international context:

1. What explains the sports performance of the clubs in the national championships?

2. How can the digital platform model enhance club business?

3. Proposals for structuring the Brazilian football industry with a master plan common to all clubs.

4. What factors determine the engagement of fans?

5. Factors inducing the creation of startups in the sports world (sportstechs).

6. Club internationalization strategies in an increasingly globalized world.

7. Club financial fundamentals and their impact on sports performance.

8. Social and demographic profile of soccer club fans and their implications for marketing strategies.

9. What are the advantages and disadvantages in relation to transforming clubs into companies in the Brazilian context?

10. Diversity in the context of football and club strategies.

11. The social impact of football clubs around the world.

12. Compared models of strategies and management of arenas and stadiums.

We are sure that the academic area has a lot to contribute to the world of football, which, as we seek to express in this letter, is already economically relevant and has the potential to be more and more, not to mention the social benefits that sport in general provides for all, but especially for the most disadvantaged section of the population.

\section{REFERENCES}

Confederação Brasileira de Futebol. (2019). Relatório impacto do futebol Brasileiro. Retrieved from https://doi.org/10.5281/ zenodo. 4587228 


\section{AUTHORSHIP}

\section{Wilson Toshiro Nakamura}

Sociedade Esportiva Palmeiras

Rua Palestra Itália, 214, Perdizes, 05005-030, São Paulo, SP, Brazil.

Email address: wilson.nakamura@palmeiras.com.br

(D) https://orcid.org/0000-0002-4697-5685

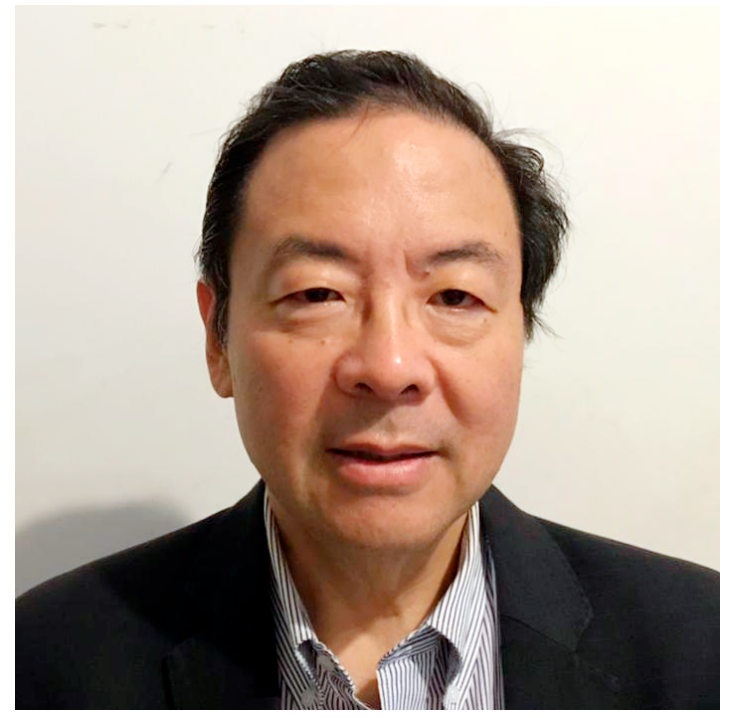

Full Professor of faculty of the Graduate Program in Business Administration at Universidade Presbiteriana Mackenzie. PhD and Master in Administration from FEA-USP. Bachelor in Administration, Economics and Accounting from FEA-USP. Bachelor of Laws from USP Law School. Business consultant. Titular member of the Fiscal Council of the Brazilian Finance Society. Member of the Scientific Editorial Board of the Revista de Administração de Empresas - RAE. Associate Editor of Rausp Management Journal. CNPq Level 2 Research Productivity Scholarship. Evaluator of Fapesp projects. Member of the Scientific Development Committee of CRC-SP. Theme Leader in the Finance Division of Anpad. Theme Leader in the Finance area of SemeAd.

\section{Sérgio de Albuquerque Cerqueira}

Mansão Botafogo

Avenida Venceslau Brás, no 72, Botafogo, 22290-140, Rio de Janeiro, RJ, Brazil.

Email address: java.rjcerqueira@gmail.com

(D) https://orcid.org/0000-0002-2141-972X

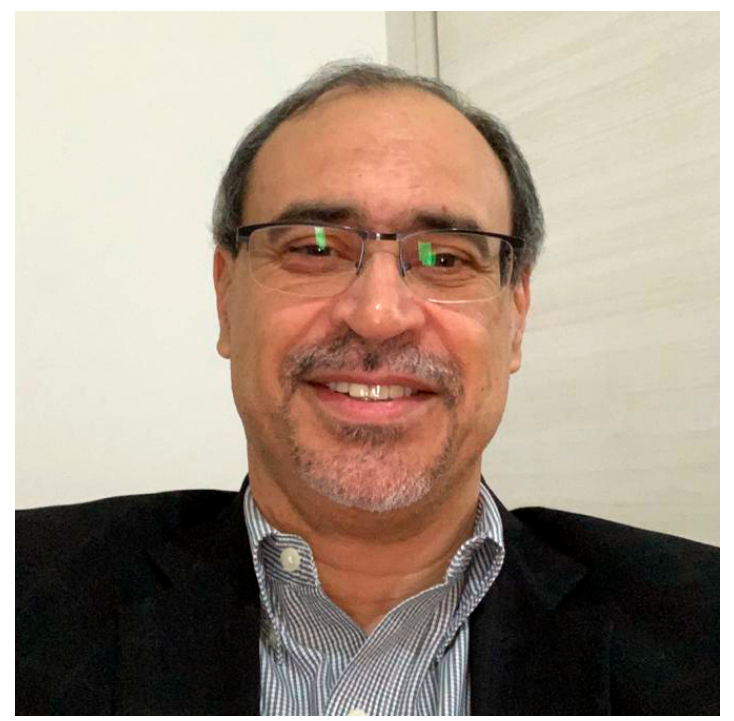

IT Governance Analyst at Previ - Caixa de Previdência dos Funcionários do Banco do Brasil (Banco do Brasil Employee Pension Fund). Postgraduate in IT Governance and Best Practices from the INFNET Institute. Postgraduate in Sports Management from FGV/FIFA. Certified in Football Management by IGoDD - Instituto Goiano de Direito Desportivo (Goiano Institute of Sports Law). Bachelor of Computer Science from Veiga de Almeida University. Member of IBGC - Instituto Brasileiro de Governança Corporativa (Brazilian Institute of Corporate Governance).

Note: Executive Letters are documents published since January 2021 by the Journal of Contemporary Administration (Revista de Administração Contemporânea), and serve the role of enabling and establishing dialogue between the community of practitioners and the academic community in the field of business and management. The main intention of publishing the Executive Letters is to consolidate and guide the social impact of scientifically rigorous research in this field. These documents must contain, as a priority, the opinion, at the individual level, of people who exercise leadership in sectors of industry or public management about problems relevant to their performance. To that end, these documents should address contexts and problems faced by leaders, who can be reflected in a research target in the business and management area. The Executive Letters will be authored by individuals invited by RAC Editors. 


\section{Conflict of Interests}

The author have stated that there is no conflict of interest.

\section{Copyrights}

RAC owns the copyright to this content.

\section{Plagiarism Check}

The RAC maintains the practice of submitting all documents approved for publication to the plagiarism check, using specific tools, e.g.: iThenticate.

\section{WHAT IS THE JOURNAL OF CONTEMPORARY ADMINISTRATION?}

The Journal of Contemporary Administration (Revista de Administração Contemporânea - RAC) was established in 1997 and is published bimonthly (continuous publication) by ANPAD (Brazilian Academy of Management), with openaccess to its full text (peer-reviewed) content online. Registered under ISSN 1982-7849 (online) and ISSN 1415-6555 (print version from 1997 to 2010). The journal publishes articles on theoretical development and theoretical-empirical work in the area of Administration and Accounting, aligned with Open Science practices: open data, materials and open source, as well as the dissemination of additional information related to the editorial process. This journal is a member of, and subscribes to the principles of, the Committee on Publication Ethics (COPE) for scholarly publication. The Journal of Contemporary Administration (RAC) is the leading academic journal in its field, with high quality peer-reviewed contributions. Therefore, we pay special attention to the role of RAC: to be a reliable source of data, information, and knowledge. In addition, RAC, through its editorial scope, prioritizes works that explore themes relevant to society. To do so, it uses the themes highlighted in the UN Sustainable Development Goals (SDGs). RAC is a pluralistic and unorthodox business journal in the field of management research, primarily concerned with issues relating to the links between strategy and competitive management, and provides research findings on systems and standards, corporate management tools, organizations and management, specific industry sectors, and answers to contemporary issues such as development, community resilience, inequality, consumption, technology, and climate change.

\section{Indexers and Directories}

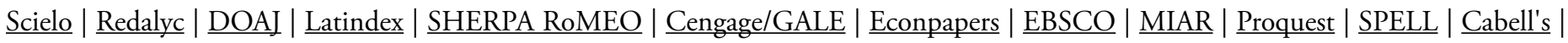
Ulrichs | CLASE | DIADORIM | ERIHPlus | EZB | EuroPub | OasisBR | WorldWideScience | Google Scholar | Capes/Qualis 